Chirurgia (2019) 114: 290-294

No. 2, March - April

Copyright@ Celsius

http://dx.doi.org/10.21614/chirurgia.114.2.290

\title{
Peritoneal Encapsulation - A Rare Cause of Small Bowel Obstruction
}

\author{
Elena-Adelina Toma', Cosmin Giulea', Octavian Enciu ${ }^{1,2}$, Valentin Calu ${ }^{1,2}$, Adrian Miron ${ }^{1,2}$ \\ ${ }^{1}$ Surgery Department, Elias University Emergency Hospital, Bucharest, Romania \\ 2"Carol Davila" University of Medicine and Pharmacy, Bucharest, Romania
}

Corresponding author:

Valentin Calu, MD

Surgery Department

Elias University Emergency Hospital

17, Marasti Blvd., District 1,

Bucharest, Romania

E-mail: drcalu@yahoo.com

\section{Rezumat}

Încapsularea peritoneală - o cauză rară de obstructie a intestinului subtire

Incapsularea peritoneală (IP) este o anomalie anatomică rară care apare din cauza unui sac peritoneal accesor care acopera intestinul subțire şi poate cauza durere abdominala cronică recurentă şi chiar ocluzie intestinala înaltă, cel mai frecvent la copii sau pacienți fără antecedente chirurgicale. Diagnosticul pozitiv este de obicei intraoperator, dar recent s-a sugerat posibilitatea diagnosticării imagistice, printr-o analiză amănunțită a CT-ului abdominal preoperator. Prezentăm cazul unui pacient de 21 ani internat pentru durere abdominală intensă, distensie abdominală asimetrică, nivele hidro-aerice prezente pe radiografia abdominală, dar fără cauză decelabilă CT. S-a intervenit chirurgical de urgență şi s-a descoperit IP, cu excizia consecutivă a sacului peritoneal. Evoluția postoperatorie a fost favorabilă. Examinarea histopatologică a piesei a confirmat diagnosticul. IP este deseori diagnosticat eronat ca peritonită sclerozantă încapsulată sau cocoon abdominal, dar este o patologie cu o rată de recurență mult mai scăzută şi rare complicații postoperatorii, ce poate fi tratată cu succes dacă operatorul ia în considerare această patologie la momentul diagnosticului diferențial.

Cuvinte cheie: încapsulare peritoneală, ocluzie intestin subțire, cocoon abdominal, anomalie anatomică 


\begin{abstract}
Peritoneal encapsulation (PE) is a rare anatomic anomaly which occurs due to an accessory peritoneal sac covering the small bowel which can cause chronic recurrent abdominal pain and even small bowel obstruction, most often in children or patients with no previous surgical history. The diagnosis is usually made during surgery, but recently it has been suggested that mindful examination of the abdominal CT may be helpful in considering PE beforehand. We present the case of a 21-year old patient who was admitted due to intense abdominal pain, asymmetrical abdominal distension, air fluid levels on the abdominal X-ray, but no specific findings on the abdominal CT. He underwent emergency surgery and PE was found and the peritoneal sac was excised. The postoperative course was uneventful. Histopathologic examination of the specimen confirmed the diagnosis. $\mathrm{PE}$ is often misdiagnosed as abdominal cocoon or sclerosing encapsulating peritonitis, but it is a pathology with a much lower rate of recurrence and postoperative complications, which can be treated successfully if the surgeon is aware of this pathology when making the differential diagnosis.
\end{abstract}

Key words: peritoneal encapsulation, small bowel obstruction, abdominal cocoon, anatomic anomaly

\section{Introduction}

First reported by Cleland in 1868 (1), peritoneal encapsulation is an abnormal secondary peritoneal sac that encompasses the entire small intestine and communicates with the bigger peritoneal cavity through a small aperture at the ileocecal junction. Very few cases have been reported in literature, the diagnosis usually being made during surgery, with some authors suggesting more recently that a preoperative CT diagnosis is possible (2).

We report a rare case of acute small bowel obstruction in a 21-year old male with no significant medical history, no previous abdominal surgeries and no previously diagnosed hereditary conditions.

\section{Case report}

A 21-year old man was brought to the emergency room complaining of intense diffuse abdominal pain that had debuted 12 hours prior associated with non-bilious vomiting and the absence of bowel movements for 4 days. At admission the patient had no fever and the vital signs were normal.

The physical examination revealed moderate abdominal distension, slightly asymmetrical favouring the left abdomen (which worsened after admission) with tenderness in the left upper and lower quadrants. Rectal examination revealed the absence of stool in the anal canal and lower rectum. The white blood cell count was $14370 / \mathrm{mm}^{3}$ ( $84.7 \%$ neutrophils), with normal findings across the rest of the blood panel.

The abdominal ultrasound showed dilated bowel loops in the central abdominal and pelvic regions and the intestinal wall was apparently thickened. No free fluid was visible in the abdominal cavity. A plain abdominal X-ray revealed a slightly dilated small bowel loop (maximum diameter of $38 \mathrm{~mm}$ ), with multiple air fluid levels, located in the lower left quadrant, with no signs of pneumoperitoneum. An emergency contrast enhanced abdominal computerized tomography (CT) was performed, which revealed a distended stomach, duodenum and small bowel loops (Fig. 1), with multiple intraluminal air fluid levels, thickened walls, with no signs of acute vascular distress. In the right lower quadrant, there was an area of abrupt transition from a dilated bowel loop to normal-looking loops, with no visible cause for obstruction. 


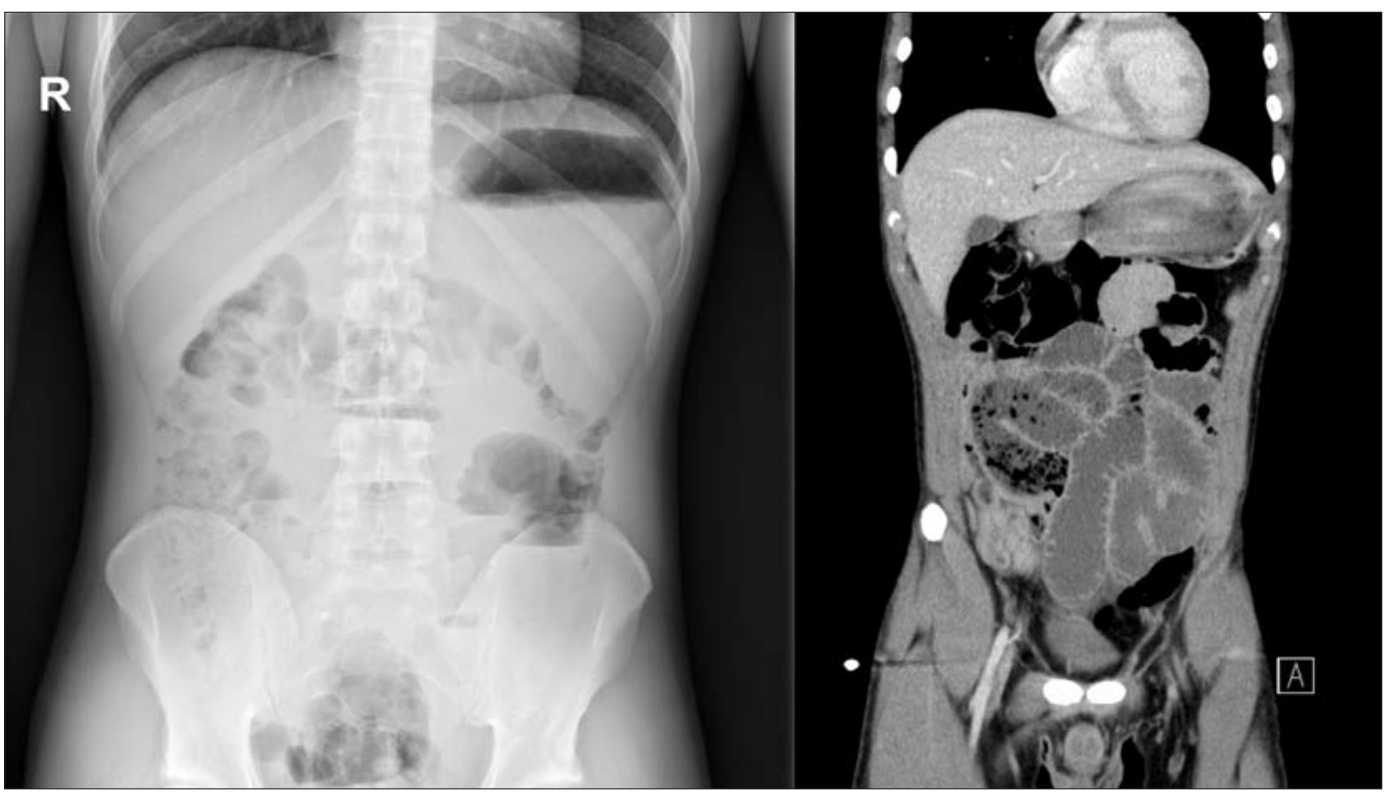

Figure 1. Plain abdominal X-ray and abdominal CT demonstrating air fluid levels

Considering the $\mathrm{CT}$ diagnosis of small bowel obstruction of uncertain cause with no other significant findings, an emergency diagnostic laparotomy was performed (Fig. 2). Upon entering the abdominal cavity, an unusual nonwhitish peritoneal like membrane surrounding the entire small bowel was observed. It had similar features to the peritoneum and apparently it originated near to the duodeno-jejunal flexure, went on to the mid transverse colon and downward from the greater curvature of the stomach to the pelvic region. It communicated with the abdominal cavity through a small aperture in the ileocecal region, where it was bordered by the ascending colon which was in normal position (Fig. 3). Upon dissection of the sac, starting in the right iliac fossa, viable if moderately dilated small bowel loops were identified, with sparse adhesions, mainly around the distal ileum. Careful dissection of the entire small bowel and the sac were performed, with meticulous adhesiolysis and quasi-complete resection of the capsule. Small bowel resection was not necessary, normal peristalsis was present throughout the entirety of the jejunum and ileum.

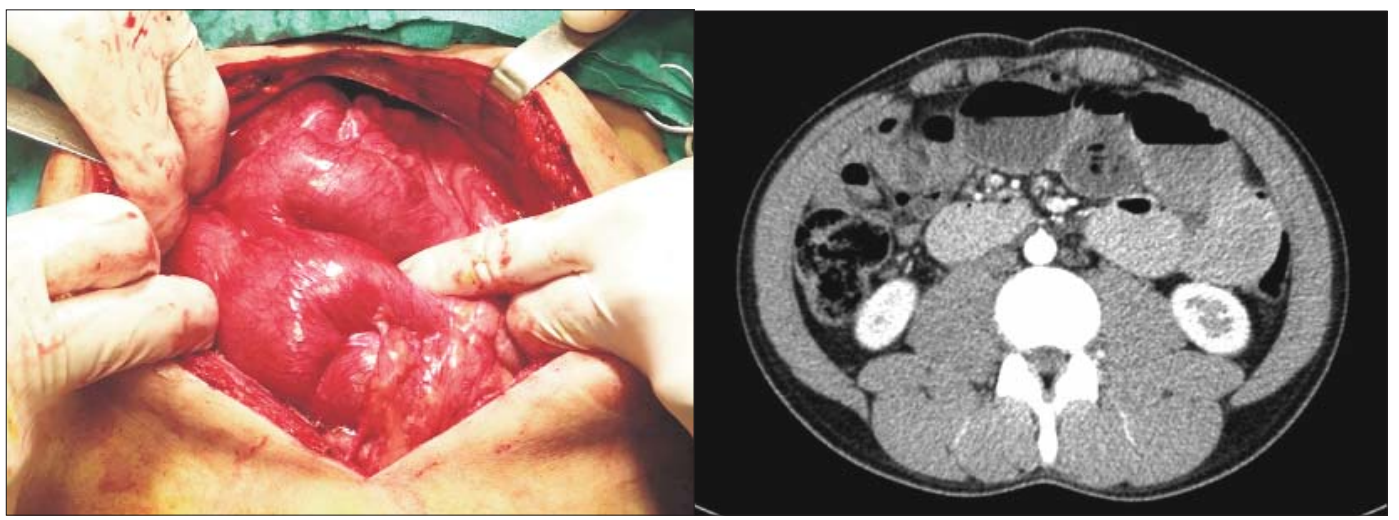

Figure 2. Peritoneal membrane covering the small intestine (CT scan comparison) 


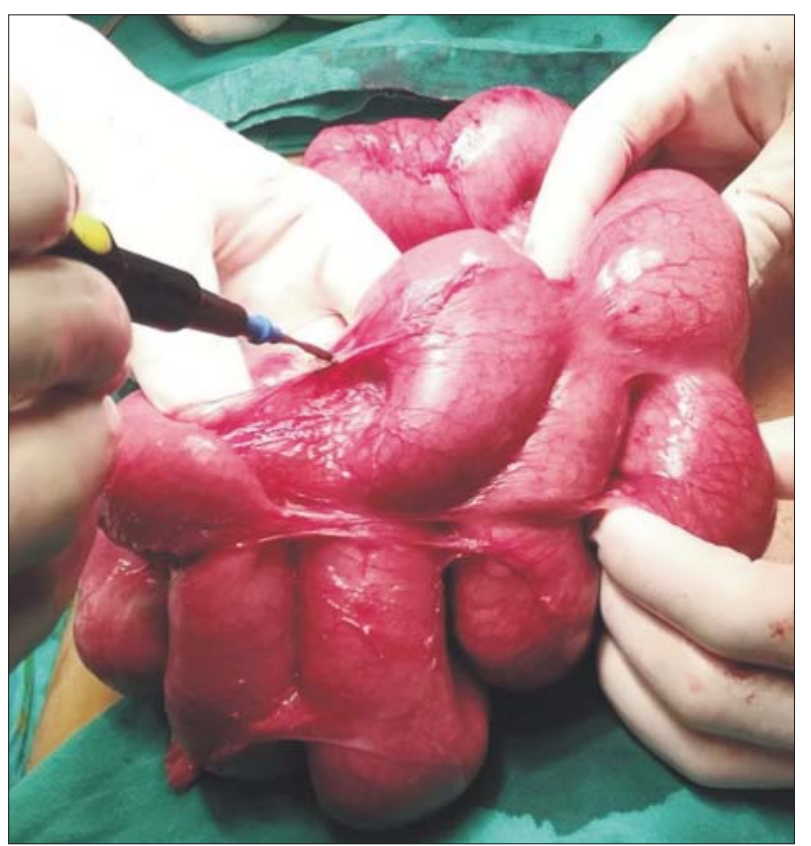

Figure 3. Peritoneal membrane (sac) - during dissection. Fragments were sent for pathology.

The postoperative course was uneventful, the patient was discharged 4 days after surgery with no abdominal pain, restored and normal bowel movements and normal blood tests. Follow-up after one and six months revealed no postoperative issues, bowel transit and digestive tolerance were reported to be normal.

The histopathological examination of the fragments of excised sac showed characteristics of fibrous and adipose tissue covered by mesothelium of peritoneal origin, as well as inflammatory cells. There was no evidence of fungal or bacterial infection.

\section{Discussion}

Peritoneal encapsulation is a rare anatomical finding, where an abnormal return of the midgut into the abdominal cavity of the fetus during the $12^{\text {th }}$ week of gestation causes the covering layer of yolk sac to encapsulate the small bowel instead of remaining in the umbilical pedicle $(2,3)$. The peritoneal accessory sac covers the small bowel partially or entirely, can be covered by the greater omentum (but it can also be absent), and usually extends from the ascending and descending colon laterally, superiorly to the mid transverse colon and inferiorly to the pelvic parietal peritoneum (4-6). This pathology should be taken into consideration when a patient with no previous surgical history presents with symptoms indicating small bowel obstruction, with a higher degree of suspicion if the patient reveals past episodes of recurring abdominal pain with no discernable cause, or upon physical examination, asymmetrical abdominal distension is observed $(7,8)$. During surgery it is very important to recognize the secondary fold of peritoneum and to remove as much as possible. Simple adhesiolysis in areas susceptible for obstruction will not suffice and recurrence is to be expected.

Even though less than 60 cases have been reported in the medical literature so far, there are hypotheses that peritoneal encapsulation might be associated with other anatomical anomalies, such as situs inversus or congenital epigastric hernia $(9,10)$. This was not the case with our patient, no other abnormalities being identified during surgery.

There are at least two other pathologies that have been wrongly reported as peritoneal encapsulation, but upon further inspection, have been categorised as having different etiologies: sclerosing encapsulating peritonitis (SEP) and the abdominal cocoon $(7,11,12)$. SEP is a condition that presents itself as a similar encapsulation of the small bowel, but with a thicker wall, more fibrous, of greywhite colour, being directly caused by certain specific aetiological factors. The factor most often cited is chronic peritoneal dialysis, but recurrent peritonitis, ventriculo-peritoneal and peritoneo-venous shunts, sarcoidosis, tuberculosis, Mediterranean fever, protein-S deficiency, following liver transplantation, systemic lupus erythematosus, and fibrogenic foreign material have also been identified as causing SEP (11,13-15). Emergency surgery in SEP has a much higher mortality than true peritoneal encapsulation (16). The abdominal cocoon is another controversial concept, still under debate as to cause and potential treatment options, but so far theories most often indicated it might be caused by retrograde 
menstruation, retrograde peritonitis and recurrent gynecological infections (17-19).

\section{Conclusions}

While peritoneal encapsulation is a rarely reported cause of small bowel obstruction, identifying certain aspects be it in the medical history of the patient or on the CT images can help the surgeon in choosing the right therapeutic approach.In this case, during emergency surgery, adhesiolysiswith complete resection of the secondary peritoneal sac ensured a smooth postoperative course. During short-term follow-up, recurrence was not reported.

\section{Conflict of Interest}

The authors declare no conflicts of interests.

\section{References}

1. Cleland. On an Abnormal Arrangement of the Peritoneum, with Remarks on the Development of the Mesocolon. J Anat Physiol. 1868;2(2):201-6.

2. Naraynsingh V, Maharaj D, Singh M, Ramdass MJ. Peritoneal encapsulation: a preoperative diagnosis is possible. Postgrad Med J. 2001;77(913):725-6.

3. Teixeira D, Costa V, Costa P, Alpoim C, Correia P. Congenital peritoneal encapsulation. World J Gastrointest Surg. 2015;7(8):174-7.

4. Arumugam PK, Dalal AK2. Peritoneal encapsulation - an unexpected cause of acute intestinal obstruction. J Visc Surg. 2017; 154(4):303-305.

5. Al-Taan OS1, Evans MD, Shami JA. An asymptomatic case of peritoneal encapsulation: case report and review of the literature.
Cases J. 2010;3:13.

6. Sherigar JM, McFall B, Wali J. Peritoneal encapsulation: presenting as small bowel obstruction in an elderly woman. Ulster Med J. 2007:76(1):42-4.

7. Stewart D, Rampersad R, King SK. Peritoneal encapsulation as a cause for recurrent abdominal pain in a 16-year-old male. ANZ J Surg. 2017; 87(5):414-415. Epub 2014 Nov 12.

8. Mordehai J, Kleiner O, Kirshtein B, Barki Y, Mares AJ. Peritoneal encapsulation: a rare cause of bowel obstruction in children.J Pediatr Surg. 2001:36(7):1059-61.

9. Zoulamoglou M, Flessas I, Zarokosta M, Piperos T, Kalles V, Tsiaousis I, et al. Congenital peritoneal encapsulation of the small intestine: A rare case report. Int J Surg Case Rep. 2016:27:28-31.

10. Ince V, Dirican A, Yilmaz M, Barut B, Ersan V, Yilmaz S. Peritoneal encapsulation in a patient with incomplete situs inversus. J Coll Physicians Surg Pak. 2012;22(10):659-60.

11. Akbulut S. Accurate definition and management of idiopathic sclerosing encapsulating peritonitis. World J Gastroenterol. 2015; 21(2):675-87.

12. Singhal M, Krishna S, Lal A, Narayanasamy S, Bal A, Yadav TD, et al. Encapsulating Peritoneal Sclerosis: The Abdominal Cocoon. Radiographics. 2019;39(1):62-77. Epub 2018 Dec 7.

13. Jenkins SB, Leng BL, Shortland JR, Brown PW, Wilkie ME. Sclerosing encapsulating peritonitis: a case series from a single U.K. center during a 10-year period. Adv Perit Dial. 2001;17:191- 5.

14. Maghrebi H, Makni A, Rhaeim R, Zehani A, Haddad A, Daghfous A, et al. Encapsulating sclerosing peritonitis : two rare observations and literature review. Tunis Med. 2018:96(1):68-71.

15. Ashok Kumar P, Sambandam S, Singh G, Kaur M, Venkataswamy C, Venkatakrishnan L, et al. Idiopathic sclerosing encapsulating peritonitis: a rare cause of intestinal obstruction. ANZ J Surg. 2018; 88(10):E730-E731. Epub 2016 Jul 24

16. Rajagopal AS1, Rajagopal R. Conundrum of the cocoon: report of a case and review of the literature. Dis Colon Rectum. 2003;46(8): $1141-3$.

17. Li S, Wang JJ, Hu WX, Zhang MC, Liu XY, Li Y, et al. Diagnosis and Treatment of 26 Cases of Abdominal Cocoon. World J Surg. 2017; 41(5):1287-1294.

18. Al-Thani H, El Mabrok J, Al Shaibani N, El-Menyar A. Abdominal cocoon and adhesiolysis: a case report and a literature review. Case Rep Gastrointest Med. 2013;2013:381950. Epub 2013 Feb 17.

19. Pandey A, Karki C, Thapa M. Abdominal Cocoon Syndrome following Primary Subfertility Management with IVF-ET." JNMA J Nepal Med Assoc. 2018;56(212):808-810. 